\title{
Surface species structure and activity in NO decomposition of an anatase-supported $\mathrm{V}-\mathrm{O}-\mathrm{Mo}$ catalyst
}

\author{
P. Kornelak ${ }^{\text {a, }}$, D.S. Su ${ }^{\text {b }}$, C. Thomas ${ }^{\text {c }}$, J. Camra ${ }^{\text {d }}$, A. Wesełucha-Birczyńska a ${ }^{\text {, M. Toba }}{ }^{\text {e, }}$ \\ M. Najbar ${ }^{\text {a }}$ \\ ${ }^{a}$ Department of Chemistry, Jagiellonian University, Ingardena 3, 30060 Krakow, Poland \\ ${ }^{\mathrm{b}}$ Department of Inorganic Chemistry, Fritz-Haber-Institut der Max-Planck Geselleschaft, Faradayweg 4-6, D-14195 \\ Berlin, Germany \\ ${ }^{\mathrm{c}}$ Laboratoire Re'activite de Surface, CNRS UMR7609, Universite Pierre et Marie Curie, 4 Place Jussieu, 75252 \\ Paris 05, France \\ ${ }^{\mathrm{d}}$ Faculty of Materials Science and Ceramics, AGH University of Science and Technology, Mickiewicza 30, 30-059 \\ Krakow, Poland \\ e National Institute of Advanced Industrial Science and Technology, Tsukuba Central-5, 1-1-1 Higashi, Tsukuba, \\ Ibaraki 305-8565, Japan \\ * Corresponding author, E-mail address: kornelak@chemia.uj.edu.pl (P. Kornelak).
}

Keywords: Anatase-supported V-O-Mo catalyst, surface interstitial V ions, Vanadia surface species, NO decomposition

\begin{abstract}
The paper concerns the evolution of surface species of a $\mathrm{V}-\mathrm{O}-\mathrm{Mo} /$ anatase catalyst in the course of its thermal treatment in oxidising and/or reducing conditions. The catalyst was obtained by the sol-gel method. The structure of its surface was investigated by XPS and Raman spectroscopy. The fresh catalyst consists of anatase nanocrystallites with some vanadium and molybdenum ions substituted for titanium ones and molybdenum oxide islands on their surfaces. A $\mathrm{V} / \mathrm{Mo}_{5} \mathrm{O}_{14}$ solid solution-containing $\mathrm{V}$ atoms in its channels, as well as $\mathrm{MoO}_{3}$ and anatase with some surface vanadia species are present on the catalyst surface. The reduction of anatase to $\mathrm{TiO}_{2 \_}$and of $\mathrm{MoO}_{3}$ to $\mathrm{Mo}_{5} \mathrm{O}_{14}$, accompanied by inward vanadium diffusion occurs during the catalyst interaction with ammonia at $523 \mathrm{~K}$. The oxidation of the $\mathrm{TiO}_{2 \times}$ but not $\mathrm{Mo}_{5} \mathrm{O}_{14}$ and $\mathrm{V}$ reappearance in the surface channels take place during the interaction of the reduced catalyst with molecular oxygen. However, the oxidation of $\mathrm{Mo}_{5} \mathrm{O}_{14}$ to $\mathrm{MoO}_{3}$ occurs under the influence of atomic oxygen, formed by $\mathrm{NO}$ decomposition at $423 \mathrm{~K}$. It is accompanied by the surface vanadia species formation. The activity of $\mathrm{V}$ ions of these species in NO decomposition is lower than of the surface interstitial ones.
\end{abstract}

\section{Introduction}

Anatase-supported vanadia-based catalysts are the best catalysts for the selective catalytic reduction of $\mathrm{NO}_{\mathrm{x}}(\mathrm{x}=1$ or 2$)$ by ammonia $\left(\mathrm{NH}_{3}-\mathrm{SCR}\right)$ to $\mathrm{N}_{2}$ and $\mathrm{H}_{2} \mathrm{O}$ in oxygen presence [1-6]. Anatase is known as a structural support for $\mathrm{V} 2 \mathrm{O} 5$ catalysts due to the good crystallographic phase matching [7]. Anatasesupported vanadia-tungsta catalysts are commonly used to remove NO from stationary sources of emission. Molybdena-vanadia catalysts, though less active than vanadia-tungsta ones, are frequently used to reduce NO in off-gases containing arsenic [8]. Their resistance to poisoning by arsenic is much higher than the resistance of $\mathrm{V}-\mathrm{O}-\mathrm{W}$ catalysts. Vanadia surface species are commonly considered as responsible for the $\mathrm{NH}_{3}-\mathrm{SCR}$ activity of all the vanadia-based catalysts [1-6].

Structures of the vanadia surface species of European industrial catalysts $-\mathrm{V}_{2} \mathrm{O}_{5} / \mathrm{TiO}_{2}$ for selective toluene oxidation to maleic anhydride and $\mathrm{V}_{2} \mathrm{O}_{5}-\mathrm{WO}_{3} / \mathrm{TiO}_{2}$ one for $\mathrm{NH}_{3}-\mathrm{SCR}$ of $\mathrm{NO}_{\mathrm{x}}$ - were widely discussed in special issues of Catalysis Today $[9,10]$.

It has recently been found that surface species of $\mathrm{V}-\mathrm{O}-\mathrm{W} /$ rutile catalyst with a vanadia structure show relatively high activity in direct $\mathrm{NO}$ decomposition to dinitrogen and dioxygen in oxygen presence at 423-453 K [11-13]. Such species are formed as a result of an vanadium segregation on the surfaces of the nanocrystallites of rutile and tungsten oxides during the thermal treatment of the catalyst in oxygen [14]. We expected that analogous species could be formed on anatase-supported $\mathrm{V}-\mathrm{O}-\mathrm{Mo}$ catalyst surface and could be active in NO decomposition in oxygen presence. 
Depero et al. $[15,16]$ have shown that V/anatase and W/anatase solid solutions are formed by laserinduced pyrolysis of alkoxides. Vanadia was shown to segregate from $\mathrm{V} / \mathrm{TiO}_{2}$ solid solution as a result of the catalyst thermal treatment in air [15]. However, Wcontaining solid solution has not shown any change during the thermal treatment [16]. The radii of $\mathrm{W}^{5+}$ and $\mathrm{Mo}^{5+}$ ions in octahedral coordination are almost the same $(0.62$ and $0.61 \AA$, respectively [17]). Thus, the formation of the mixed $\mathrm{V}+\mathrm{Mo} /$ anatase solid solution could also be expected. On the other hand, it is known that vanadia dissolves in some molybdenum sub oxides [18,19] whereas its dissolution in molybdena is rather low [20].

It was scheduled to obtain an anatase-supported V-O-Mo catalyst by preparing a solid solutions of molybdena and vanadia in anatase and possibly vanadia in some molybdenum oxide and next forming vanadia surface species via oxidation-induced surface $\mathrm{V}$ segregation. To obtain such species on the catalyst surface the same procedure as in the case of $\mathrm{V}-\mathrm{O}-\mathrm{W} /$ rutile catalyst $[12,13]$ was applied. It consists of a mild reduction of the freshly prepared catalyst by ammonia to cause dissolution of adventitious vanadium surface species and next oxidation-induced surface $\mathrm{V}$ segregation resulting in the gradual formation of the species active in NO decomposition. It was planned to investigate the influence of the content and structure of the surface vanadium species on the catalyst activity in NO decomposition in oxygen presence. The XPS and Raman spectroscopy were used to monitor the structure of the surface of the catalyst after particular stages of the synthesis and after use of the catalyst in NO decomposition.

\section{Experimental}

\subsection{Catalyst preparation}

A precursor of an anatase-supported $\mathrm{V}-\mathrm{O}-\mathrm{Mo}$ catalyst with the ratio $\mathrm{V}: \mathrm{Mo}: \mathrm{Ti}=1: 9: 90$, analogous to that in the $\mathrm{V}-\mathrm{O}-\mathrm{W} /$ rutile catalyst $[12,13]$, was prepared by the sol-gel method from water solutions of $\left(\mathrm{NH}_{4}\right)_{6} \mathrm{Mo}_{7} \mathrm{O}_{24} \cdot 4 \mathrm{H}_{2} \mathrm{O}$ and $\mathrm{VO}\left(\mathrm{NO}_{3}\right)_{2}$ as well as a $6 \% \mathrm{TiO}_{2}$ sol solution. The details of the synthesis were presented elsewhere [21]. The precursor of the catalyst was calcinated at $773 \mathrm{~K}$ in air for $3 \mathrm{~h}$. The specific BET surface area of the catalyst is equal to $115 \mathrm{~m}^{2} / \mathrm{g}$ and the pores with the radius of $1.58 \mathrm{~nm}$ occur most frequently.

2.2. The equipment used for physico-chemical characterisation of the catalysts

A Philips CM200 TEM with a field emission gun was used to take high-resolution images. The chemical composition in the catalysts' surface nanolayers was investigated using an ESCA 150 Spectrometer (VSW Scientific Instruments) with a magnesium anode. The binding energy scalewas established by referring to the $\mathrm{C}(1 \mathrm{~s})$ value of the adventitious carbon $(284.6 \pm 0.1 \mathrm{eV})$. The vanadium $2 \mathrm{p}$ bands were deconvoluted to the peaks corresponding to $\mathrm{V}^{5+}\left(\mathrm{V}_{2} \mathrm{O}_{5}\right), \mathrm{V}^{4+}\left(\mathrm{V}_{2} \mathrm{O}_{4}\right), \mathrm{V}^{3+}\left(\mathrm{V}_{2} \mathrm{O}_{3}\right)$ and $\mathrm{V}^{2+}(\mathrm{VO})$ ions $[22-$ 24]. The molybdenum $3 \mathrm{~d}$ bands were deconvoluted to the peaks corresponding to $\mathrm{Mo}^{6+}\left(\mathrm{MoO}_{3}\right)$ and $\mathrm{Mo}^{5+}$ $\left(\mathrm{Mo}_{2} \mathrm{O}_{5}\right)$ ions $[22,23,25]$. The deconvolution was performed using Gaussian-Lorentzian sum function with $20 \%$ Gaussian and $80 \%$ Lorentzian values. In a quantitative analysis of the XPS bands, the following atomic sensitivity factors (ASF) were used: Ti $2 p=1.8$, Mo $3 d=2.75$ and V $2 p=1.95$ [26]. A Bio-Rad FT Raman spectrometer with a Spectra Physics Nd YAG Laser with an excitation line of $1064 \mathrm{~nm}$ was used to register the spectra. The sampling width was $2 \mathrm{~cm}^{-1}$.

\subsection{Nitric oxide decomposition}

NO decomposition was investigated in a flow quartz reactor connected with nitrogen oxides' detectors. $0.20 \mathrm{~g}$ of a catalyst was placed on silica wool in the bottom part of the quartz U-tube with $6 \mathrm{~mm}$ internal diameter and ca. $30 \mathrm{~mm}$ total length. The $\mathrm{NO}$ decomposition was carried out at $423 \mathrm{~K}$ on the catalyst previously reduced at $613 \mathrm{~K}$ with $5 \% \mathrm{NH}_{3} / \mathrm{Ar}\left(40 \mathrm{~cm}^{3} / \mathrm{min}\right)$ for $0.5 \mathrm{~h}$ and next oxidised at $773 \mathrm{~K}$ for $3 \mathrm{~h}$ and at $613 \mathrm{~K}$ for $20 \mathrm{~h}$ in an $\mathrm{O}_{2}$ stream $\left(30 \mathrm{~cm}^{3} / \mathrm{min}\right)$. The feed containing $700 \mathrm{ppm} \mathrm{NO}$ and $8 \% \mathrm{O}_{2}$, was introduced into the reactor with GHSV $125,000 \mathrm{~h}^{-1}$ (Brooks Mass Flowcontroler 5850). An $\mathrm{NO}_{\mathrm{x}}$ chemiluminescence detector CLD 700 AL Eco Physics was used for $\mathrm{NO}$ and $\mathrm{NO}_{2}$ continuous analysis. An Ultramat 6 IR analyser was applied for $\mathrm{N}_{2} \mathrm{O}$ determination.

\section{Results and discussion}

The XRD pattern of the catalyst fits the one of anatase. The average crystallite size in the [101] direction, calculated using Scherrer equation [27] is equal to $6.7 \mathrm{~nm}$ [21]. Some TEM, EDS, UV-vis and EPR results, which would be published elsewhere [28], should be mentioned here. A dark field TEM image shows anatase nanocrystallites with the average dimensions ca. $7 \mathrm{~nm}$ as the one and only distinguishable phase [28]. The vanadium and molybdenum contents, calculated from the EDX spectra taken from one nanocrystallite with limited participation of neighbouring ones are close to the nominal ones [28]. 
In a diffuse reflectance UV-vis spectrum vanadia is well visible but anatase is hardly seen [28]. An unexpectedly high absorption at wavenumbers lower than $16,000 \mathrm{~cm}^{-1}$ reveals $\mathrm{V}^{(5-\mathrm{x})+} \rightarrow \mathrm{Mo}^{6+}$ electron transfer and point to the presence of the vanadium atoms at lower oxidation states in molybdenum oxide structure.

EPR spectra at room temperature as well as at $77 \mathrm{~K}$ show the hyperfine structures of the dispersed $\mathrm{V}^{4+}$ ions in two different surroundings. It suggests the dissolution of vanadium in anatase structure and partial reduction of the surface vanadia species.

A band from $\mathrm{Mo}^{5+}$ ions is seen only in the EPR spectrum at $77 \mathrm{~K}$ because the Mo $4 \mathrm{~d}$ levels of the surface molybdenum oxides lie just at the higher energy limit of the $\mathrm{TiO}_{2}$ gap [29].

The presence of $\mathrm{Ti}^{3+}$ ions revealed by EPR could be the result of charge compensation accompanying $\mathrm{Mo}^{5+}$ substitution for $\mathrm{Ti}^{4+}$.

The presence of the observed $\mathrm{O}_{2}^{-}$radicals point to some reduction of the catalyst surface [28].

In Fig. 1, the typical HRTEM image of the fresh catalyst with an anatase nanocrystallite $(8 \mathrm{~nm} \times 9 \mathrm{~nm})$ of elliptic cross-section and well seen (011), (112) and (101) planes in the right upper corner is demonstrated. The smaller and larger anatase nanocrystallites with a different degree of crystallinity and different orientations can be distinguished. The shadows on the structure of a nanocrystallite visible in the lower part of the image can be ascribed to the presence of the $\mathrm{V}-\mathrm{O}$ and/or Mo-O surface species.

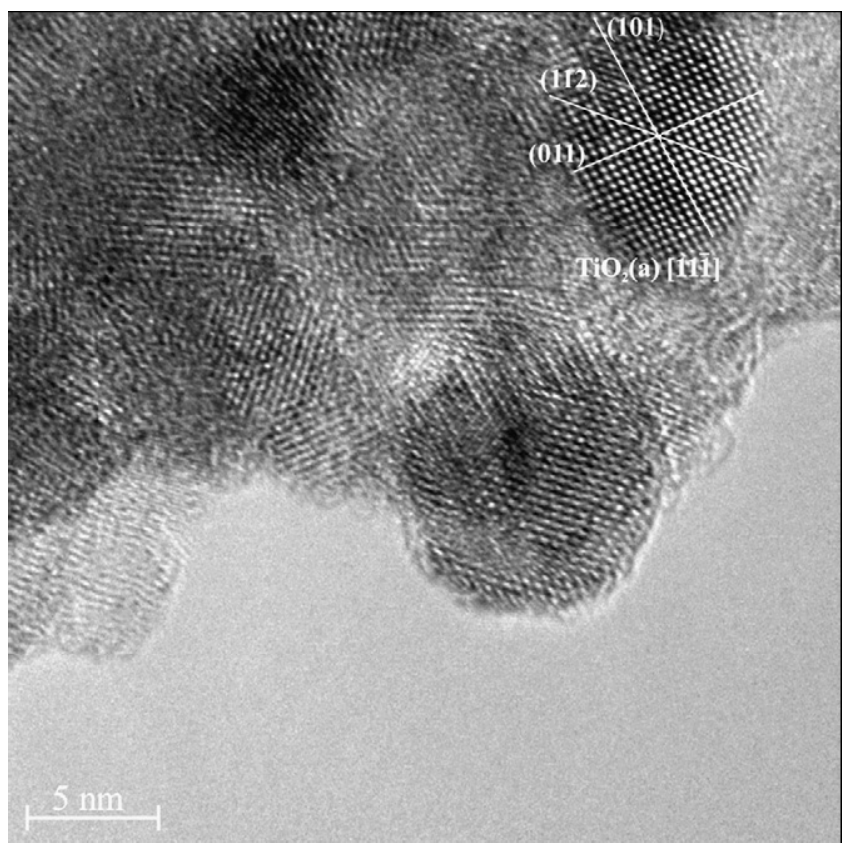

Fig. 1. HRTEM image of the fresh V-O-Mo/anatase catalyst, an anatase nanocrystallite with well seen (011), (112) and (101) planes belonging to [11-1]zone is visible in the right upper corner of the image.

Table 1

The XPS results for the fresh catalyst stored in ambient conditions for several months $(\mathrm{F})$, the catalyst reduced in the stream of $\mathrm{NH}_{3} / \mathrm{He}$ for $30 \mathrm{~min}(\mathrm{R})$, the catalyst reduced with $\mathrm{NH} 3$ and next oxidised first at $773 \mathrm{~K}$ for $3 \mathrm{~h}$ and then at $613 \mathrm{~K}$ for $20 \mathrm{~h}$ in the oxygen stream $\left(\mathrm{O}_{\mathrm{x}}\right)$, the oxidised catalyst used for $\mathrm{NO}$ decomposition in $\mathrm{O}_{2}$ presence $(423 \mathrm{~K}$, $700 \mathrm{ppm} \mathrm{NO}, 8 \% \mathrm{O}_{2}$, GHSV $\left.=125,000 \mathrm{~h}^{-1}\right)(\mathrm{NO})$

\begin{tabular}{|c|c|c|c|c|c|c|c|c|c|c|c|c|c|c|c|c|}
\hline \multirow[t]{2}{*}{ Catalyst } & $\mathrm{V}^{5+}$ & & $\mathrm{V}^{4+}$ & & $\mathrm{V}^{3+}$ & & $\mathrm{V}^{2+}$ & & $\Sigma \mathrm{V}$ & $\mathrm{Mo}^{6+}$ & & $\mathrm{Mo}^{5+}$ & & $\Sigma \mathrm{Mo}$ & $\mathrm{Ti}$ & \\
\hline & $\begin{array}{l}\mathrm{BE} \\
(\mathrm{eV})\end{array}$ & $\begin{array}{l}\mathrm{c} \\
(\%)\end{array}$ & $\begin{array}{l}\mathrm{BE} \\
(\mathrm{eV})\end{array}$ & $\begin{array}{l}\mathrm{c} \\
(\%)\end{array}$ & $\begin{array}{c}\mathrm{BE} \\
(\mathrm{eV})\end{array}$ & $\begin{array}{l}\mathrm{c} \\
(\%)\end{array}$ & $\begin{array}{l}\mathrm{BE} \\
(\mathrm{eV})\end{array}$ & $\begin{array}{l}\mathrm{c} \\
(\%)\end{array}$ & $\begin{array}{l}\mathrm{c} \\
(\%)\end{array}$ & $\begin{array}{c}\mathrm{BE} \\
(\mathrm{eV})\end{array}$ & $\begin{array}{l}\mathrm{c} \\
(\%)\end{array}$ & $\begin{array}{c}\mathrm{BE} \\
(\mathrm{eV})\end{array}$ & $\begin{array}{l}\mathrm{c} \\
(\%)\end{array}$ & $\begin{array}{l}\mathrm{c} \\
(\%)\end{array}$ & $\begin{array}{l}\mathrm{BE} \\
(\mathrm{eV})\end{array}$ & $\begin{array}{l}\mathrm{c} \\
(\%)\end{array}$ \\
\hline $\mathrm{F}$ & 517.5 & 0.8 & 516.3 & 0.4 & 515.3 & 0.3 & 514.6 & 0.1 & 1.6 & 232.2 & 10.4 & 231.0 & 2.0 & 12.4 & 458.9 & 86.0 \\
\hline $\mathrm{R}$ & 517.5 & 0.0 & 516.3 & 0.0 & 515.5 & 0.5 & 514.6 & 0.0 & 0.5 & 232.5 & 7.9 & 231.3 & 4.9 & 12.8 & 458.6 & 86.7 \\
\hline Ox & 517.5 & 0.0 & 516.3 & 0.2 & 515.5 & 0.0 & 514.3 & 0.1 & 0.3 & 232.3 & 7.7 & 231.1 & 5.2 & 12.9 & 458.7 & 86.8 \\
\hline NO & 517.5 & 0.4 & 516.3 & 0.1 & 515.5 & 0.2 & 514.3 & 0.1 & 0.8 & 232.6 & 13.3 & 231.4 & 0.3 & 13.6 & 458.8 & 85.6 \\
\hline
\end{tabular}

c, at. $\%$ of cations. 
The XPS results for the catalysts: F, freshly prepared and next stored for several months in ambient conditions; R, reduced at $613 \mathrm{~K}$ in $8 \% \mathrm{NH}_{3} / \mathrm{He}$ flow for $0.5 \mathrm{~h}$; $\mathrm{O}_{\mathrm{x}}$, thermally treated in ammonia and next oxidised at $773 \mathrm{~K}$ in $\mathrm{O}_{2}$ stream for $3 \mathrm{~h}$ and at $613 \mathrm{~K}$ for $20 \mathrm{~h}$; $\mathrm{NO}$, used in $\mathrm{NO}$ decomposition in $\mathrm{O}_{2}$ presence after reducing and next oxidising pretreatments are presented in Table 1.

The contents of vanadium and molybdenum in the surface nanolayers of the stored catalyst are 1.6 and 1.4 times higher than the nominal ones, respectively. The comparison of these results with those obtained by XRD, EDXS, HRTEM and diffuse reflectance UV-vis allows one to draw the conclusion that our catalyst is composed of anatase nanocrystallites with molybdenum oxide islands on their surface and some vanadium species on the top of those islands.

The $\mathrm{V}^{5+}$ ions can be representative for vanadia surface species. Substitution of $\mathrm{V}^{5+}(\mathrm{r}=54 \mathrm{pm}$ [17]) ions for $\mathrm{Ti}^{4+}\left(\mathrm{r}=61 \mathrm{pm}\right.$ [17]) ones in octahedral positions of anatase or for $\mathrm{Mo}^{6+}(\mathrm{r}=59 \mathrm{pm}$ [17] $)$ or $\mathrm{Mo}^{5+}(\mathrm{r}=$ $61 \mathrm{pm}$ ) in the same positions in molybdenum oxide islands seems to be less favourable because of the rather big differences in the ionic radii. It should be noticed that ammonia forming as a result of the ammonium ions decomposition at the beginning of the precursor calcination acts as a reducer and can favour incorporation of the vanadium ions at lower degrees of oxidation into the anatase nanocrystallites or into the molybdenum oxide islands. Vanadium is known to dissolve well in the $\mathrm{Mo}_{5} \mathrm{O}_{14}$ and $\mathrm{MO}_{17} \mathrm{O}_{47}$ structures $[18,19]$. The unexpectedly intensive absorption at wavenumbers lowers than $16,000 \mathrm{~cm} \_1$ in UV-vis spectrum of the fresh catalyst also point to the presence of $\mathrm{V}$ ions at lower oxidation state in molybdenum oxide islands [28]. The observed $\mathrm{V}^{2+}$ ions $(\mathrm{r}=79 \mathrm{pm}$ [17]) can be present in interstitial positions of some molybdenum oxide containing channels in its structures [30,31]. Vanadium at low oxidation states was earlier observed in the channels of the oxide $\mathrm{V}-\mathrm{W}$ bronze present in $\mathrm{V}-\mathrm{O}-\mathrm{W}$ catalyst [32]. It is also possible that $\mathrm{V}^{4+}$ ions replace some Mo ones in $\mathrm{Mo}_{5} \mathrm{O}_{14}$ structure.

The thermal treatment of the catalyst at $613 \mathrm{~K}$ in flowing $8 \% \mathrm{NH}_{3} / \mathrm{He}$ for $0.5 \mathrm{~h}$ causes a significant catalyst reduction demonstrated by a noticeable decrease in the degrees of oxidation of V, Mo as well as Ti. Simultaneous significant decrease in the vanadium concentration reveals reduction-induced vanadium diffusion into the bulk of the anatase nanocrystallites below the analysed nanolayers. The average degree of the oxidation of molybdenum (5.62) in the reduced catalyst is very close to the one in $\mathrm{Mo}_{5} \mathrm{O}_{14}(5.60)$ [30]. Therefore we think that there are $\mathrm{Mo}_{5} \mathrm{O}_{14}$ islands on the reduced catalyst surface.

The lack of the distinct change in oxidation degree of molybdenum (5.60) during catalyst thermal treatment in oxygen reveals high resistance of $\mathrm{Mo}_{5} \mathrm{O}_{14}$ to oxidation by $\mathrm{O}_{2}$, which agree well with earlier observations [18,30].

The use of the catalyst in the NO decomposition at $423 \mathrm{~K}$ in the oxygen presence causes a distinct increase of the contents and oxidation degrees of vanadium and molybdenum in the analysed nanolayers and some increase of the oxidation state of titanium. It reveals oxidation of the $\mathrm{Mo}_{5} \mathrm{O}_{14}$ islands as well as of the anatase nanolayers accompanied by the oxidation-induced vanadium and molybdenum diffusion from the anatase areas placed below the analysed nanolayers to these nanolayers. That diffusion confirms vanadium incorporation into anatase structure observed during the catalyst reduction (compare $\mathrm{F}$ and $\mathrm{R}$ rows of Table 1) and reveals Mo incorporation into that structure. The appearance of the $\mathrm{V}^{5+}$ ions shows the formation of the vanadia species which can occur as a result of the $\mathrm{V}$ segregation on anatase surface and/or as a result of $\mathrm{V} / \mathrm{Mo}_{5} \mathrm{O}_{14}$ species oxidation to $\mathrm{MoO}_{3}$.

Fig. 2 shows FT Raman spectra of the same catalysts which were investigated by XPS. The spectra were taken after several hours catalyst storage in ambient conditions. They were normalised to the peak at 150 $\mathrm{cm}^{-1}$.

The anatase peaks at 150,399, 521 and $646 \mathrm{~cm}^{-1}$ arewell seen in all the spectra. Whereas the peaks at 962-970 $\mathrm{cm}^{-1}$ are well visible in the spectra of the catalysts: stored in the ambient conditions (a), oxidised (c), and used in the NO decomposition in $\mathrm{O}_{2}$ presence (d). Such peak is invisible in the spectrum of the reduced catalyst (b). However, the band at ca. $1180 \mathrm{~cm}^{-1}$ is observed in the spectra of the reduced and used catalysts and the one at $1136 \mathrm{~cm}^{-1}$ is seen in the spectra of the reduced, oxidised and used catalysts. Moreover, the EPR signal of $\mathrm{O}_{2}^{-}$radicals is observed in the spectra of the reduced and used catalysts [28] and the bands at wavenumbers close to $1200 \mathrm{~cm}^{-1}$ were earlier seen in Raman spectra of the $\mathrm{O}_{2}^{-}$ions adsorbed on the transition metal oxides [33]. Thus the bands at ca. $1180 \mathrm{~cm}^{-1}$ can be ascribed to $\mathrm{O}_{2}^{-}$ moieties adsorbed on the surface cations depleted of the terminal oxygen. On the other hand, the peak at $1136 \mathrm{~cm}^{-1}$ is observed only in the spectra of the catalyst previously subjected to the interaction with ammonia and its wavenumber corresponds to the peak of the ammonia adsorbed on the Lewis acid sites [34]. Thus, one can think that it arises from ammonia adsorbed on the bare cations on the catalyst surface. According to the earlier investigations [21] the peak at ca. $970 \mathrm{~cm}^{-1}$ corresponds to the vibrations of the exposed $\mathrm{V} \mathrm{O}$ and/or $\mathrm{Mo} \mathrm{O}$ bonds in $\mathrm{V}_{2} \mathrm{O}_{5}$-like and/or $\mathrm{MoO}_{3}$ species with molecularly adsorbed water 
molecules. In agreement with the Yin [35] results obtained by DFT calculations, water adsorbs on V O by hydrogen bonding.

The (001) $\mathrm{V}_{2} \mathrm{O}_{5}$ surface fit very well to (010) $\mathrm{MoO}_{3}$ as well as to (001) and (100) $\mathrm{TiO}_{2}$ ones [7]. Thus, the formation of the vanadia on molybdena islands or on $\mathrm{TiO} 2$ nanocrystallites can be expected. The lack of the distinct peak at $995 \mathrm{~cm}^{-1}$ from the bulk vanadyls and/or molybdenyls reveals that the layer species exposing double-bonded oxygen atoms predominate on the surface of the fresh, oxidised and used catalysts.

The large content of $\mathrm{V}^{5+}$ ions (Table 1) in the surface nanolayers of the fresh catalyst shows the presence of the vanadia monolayer species on the catalyst surface.

The lack of the peak at $962-970 \mathrm{~cm}^{-1}$ in the spectrum of the catalyst thermally treated in ammonia (b) accompanied by a decrease in the vanadium content in the surface nanolayers (Table 1) confirms the reduction of $\mathrm{V}_{2} \mathrm{O}_{5}$ monolayer species accompanied by the vanadium diffusion into the anatase structure.

The presence of the peak at ca. $968 \mathrm{~cm}^{-1}$ in the spectrum of the catalyst subjected to the thermal treatment in oxygen (c) cannot be ascribed neither to vanadia surface species because of the lack of $\mathrm{V}^{5+}$ ions nor to molybdena ones because of the $\mathrm{Mo}_{5} \mathrm{O}_{14}$ resistance to oxidation (Table 1). However, it may be attributed to terminal double-bonded oxygen in $\mathrm{Mo}_{5} \mathrm{O}_{14}$ islands and in anatase nanocrystallites.

The lack of the peak at ca. $1185 \mathrm{~cm}^{-1}$ confirms the presence of the terminal oxygen in all the surface moieties. The narrowing of the peaks from the $\mathrm{Ti}-\mathrm{O}$ stretching vibrations and the increase of their intensities confirm the anatase oxidation.

The decrease in the intensity of the peak at $970 \mathrm{~cm}^{-1}$ as a result of the oxidised catalyst interaction with $\mathrm{NO}+\mathrm{O}_{2} / \mathrm{He}$ suggests that the surface double-bonded oxygen ions are consumed for $\mathrm{NO}$ oxidation to $\mathrm{NO}_{2}$. However, the observed increase of the contents and oxidation states of molybdenum and vanadium in the surface nanolayers (Table 1) shows essential progress in the catalyst oxidation. The initial oxidation of NO by terminal oxygen was earlier observed on vanadia-tungsta catalyst by electrical conductivity measurements [36]. Moreover, the appearance of the band at $1182 \mathrm{~cm}^{-1}$ confirms depletion of the surface of double-bonded oxygen.

To follow the gradual changes of the catalyst activity in NO decomposition with the time on stream, the continuous registration of the concentrations of $\mathrm{NO}, \mathrm{N} 2 \mathrm{O}, \mathrm{NO} 2$ and $\mathrm{NO}+\mathrm{NO} 2$ were performed for $16 \mathrm{~h}$. The results of this experiment (mostly as measured signals in $\mathrm{V}$ ) are presented in Fig. 3.

The initial rapid decrease inNOandNOx concentrations followed by the rapid increase of $\mathrm{NO}_{2}$ and $\mathrm{NO}_{\mathrm{x}}$ show $\mathrm{NO}$ oxidation to $\mathrm{NO}_{2}$. It is very probable that some double-bonded oxygen is used in this oxidation and the cations deprived of this oxygen become the active sites ofNOdecomposition. The next decrease in $\mathrm{NO}$ content without changes in $\mathrm{NO}_{2}$ and $\mathrm{N}_{2} \mathrm{O}$ ones reveals $\mathrm{NO}$ decomposition to dinitrogen and dioxygen. The $\mathrm{N}_{2}$ formation in analogous conditions was confirmed using GC/MS equipment allowing for the periodical but not continuous products' analysis. The increase of the rate of NO decomposition with time on stream (a) up to the fourth hour, reveals gradual increase of the population of the active sites. The temporary decrease of the catalyst activity in fourth hour reveals a sudden change in the structure of the surface species. Such catalyst behaviour can easily be explained if remember that the interaction of the reaction mixture with the anatase surfaces causes distinct vanadium segregation in the surface nanolayers (Table 1). It can be expected that at the beginning the vanadium ions in the surface positions of the $\mathrm{Mo}_{5} \mathrm{O}_{14}$ channels are the main sites active in NO decomposition. The increase of their population up to fourth hour is probably induced by the catalyst oxidation with atomic oxygen formed due to NO decomposition. They can easily transfer electrons to antibonding $\mathrm{Q}$ orbitals of the adsorbed NO molecules causing their decomposition [12]. The temporary decrease of the catalyst activity at fourth hour can be connected with the $\mathrm{Mo}_{5} \mathrm{O}_{14} \rightarrow \mathrm{MoO}_{3}$ phase transformation in the smallest islands, accompanied by the surface vanadia species formation showing lower activity in NO decomposition than the surface vanadium atoms in the $\mathrm{Mo}_{5} \mathrm{O}_{14}$ channels. It is obvious that the smaller are $\mathrm{Mo}_{5} \mathrm{O}_{14}$ islands the faster is their oxidation. The surface vanadium segregation during the transformation can be connected with much lower solubility of $\mathrm{V}$ in $\mathrm{MoO}_{3}$ [20] than in $\mathrm{Mo}_{5} \mathrm{O}_{14}$ [18]. The further oxidation-induced increase of $\mathrm{V}$ content in the surface layers of the residual $\mathrm{Mo}_{5} \mathrm{O}_{14}$ islands causes the further increase of the catalyst activity. That increase becomes smaller with time because of the decrease in the amount of $\mathrm{Mo}_{5} \mathrm{O}_{14}$ islands and in the $\mathrm{V}$ content in their bulk. One can expect that a stationary state of the NO decomposition will be achieved when the $\mathrm{Mo}_{5} \mathrm{O}_{14} \rightarrow \mathrm{MoO}_{3}$ transformation in all the islands is completed. 


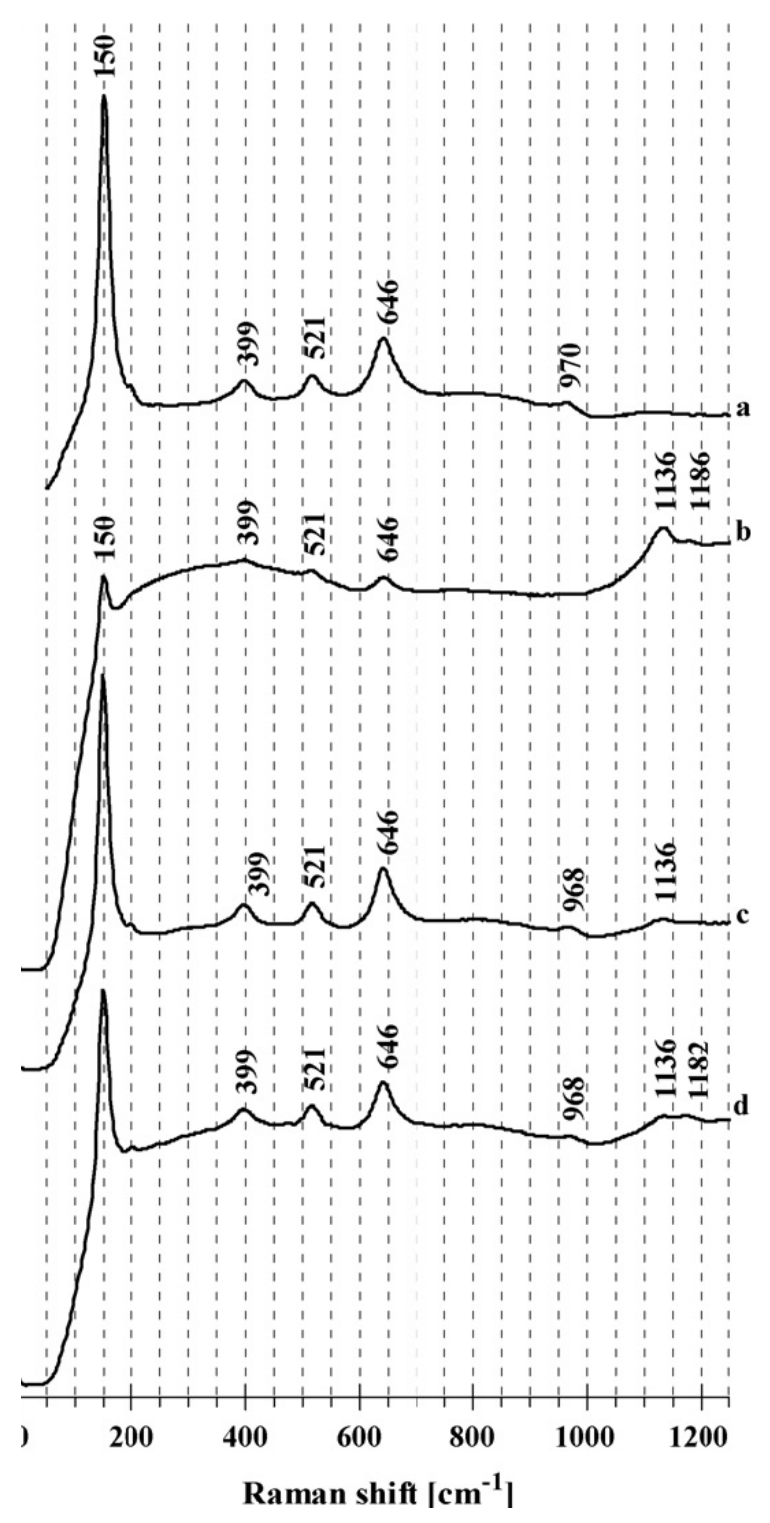

Fig. 2. The FT Raman spectra, in $50-1250 \mathrm{~cm}^{-1}$, range of the catalysts: (a) freshly prepared and next stored in ambient conditions, (b) reduced in $\mathrm{NH}_{3} / \mathrm{He}$ stream for $0.5 \mathrm{~h}$, (c) first reduced, next oxidised at $773 \mathrm{~K}_{\text {in }} \mathrm{O}_{2}$ stream for $3 \mathrm{~h}$ and at $613 \mathrm{~K}$ for $20 \mathrm{~h}$, and (d) first reduced then oxidised and finally used in NO decomposition ( $700 \mathrm{ppm} \mathrm{NO}, 8 \% \mathrm{O}_{2}, 423 \mathrm{~K}$, GHSV $\left.=125,000 \mathrm{~h}^{-1}\right)$.

\section{Conclusions}

The sol-gel method was used to synthesize the $\mathrm{V}-\mathrm{O}-\mathrm{Mo} /$ anatase $(\mathrm{V}: \mathrm{Mo}: \mathrm{Ti}=1: 9: 90)$ catalyst composed of $\mathrm{TiO}_{2}$ nanocrystallites covered by the molybdenum oxide islands containing some amount of vanadium ions either in their bulk or on their surface. The changes in the structure of the catalyst surface induced by its interaction with gas phase were investigated using XPS and Raman spectroscopy. It was found that the catalyst interaction with $8 \% \mathrm{NH}_{3} / \mathrm{He}$ at $613 \mathrm{~K}$ causes the surface reduction followed by the diffusion of the surface vanadium cations into anatase nanocrystallites. The reduction of molybdenum oxide islands leads to the $\mathrm{Mo}_{5} \mathrm{O}_{14}$ ones. The next catalyst interaction with oxygen at 773 and $613 \mathrm{~K}$ results in the oxidation of anatase but not of $\mathrm{Mo}_{5} \mathrm{O}_{14}$ islands. The initial interaction of the oxidised catalyst with $\mathrm{NO}$ causes gradual vanadium diffusion into the surface interstitial positions of $\mathrm{Mo}_{5} \mathrm{O}_{14}$ islands, resulting in the increase of the catalyst activity in $\mathrm{NO}$ decomposition. The advanced oxidation of the $\mathrm{Mo}_{5} \mathrm{O}_{14}$ islands causes $\mathrm{Mo}_{5} \mathrm{O}_{14} \rightarrow \mathrm{MoO}_{3}$ transformation followed by the formation of surface vanadia species of a bit lower activity in the NO decomposition than the one of $\mathrm{V}$ interstitial atoms. 

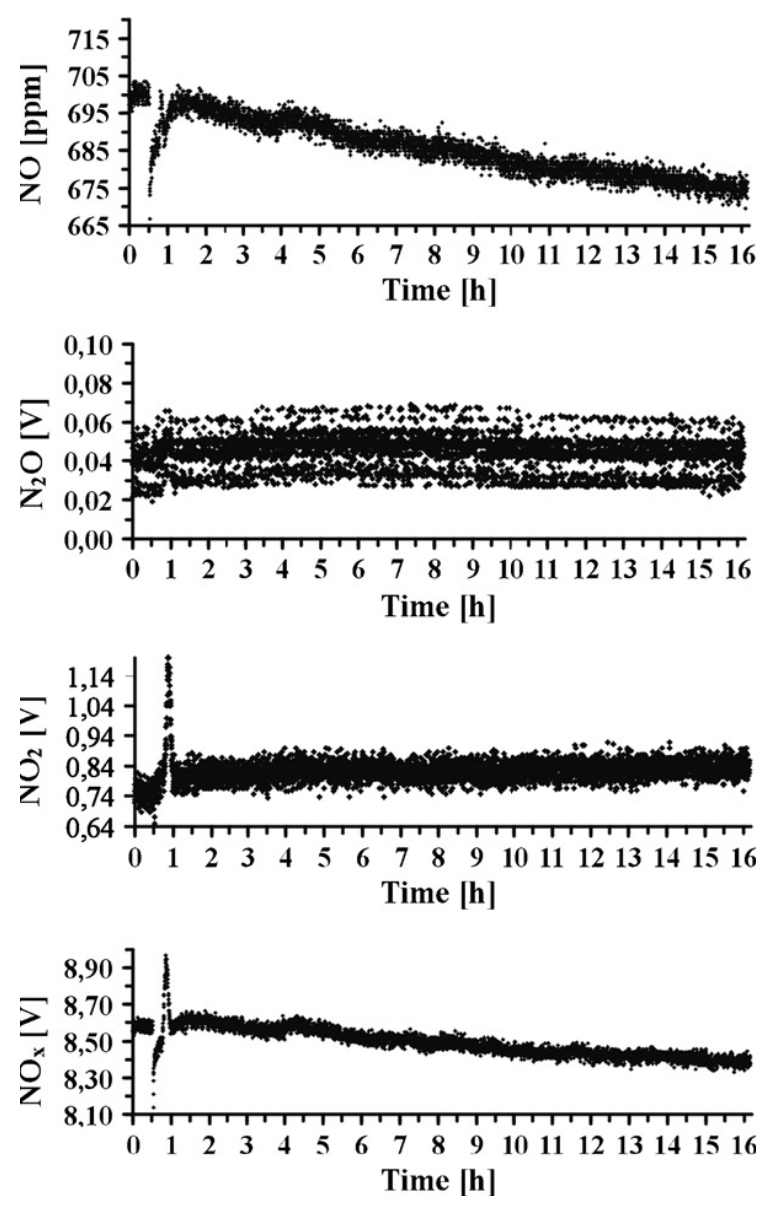

Fig. 3. $\mathrm{NO}, \mathrm{N}_{2} \mathrm{O} \mathrm{NO}$ and $\mathrm{NO}_{\mathrm{x}}$ contents in gases leaving the quartz reactor where $\mathrm{NO}$ decomposition took place (700 ppm $\mathrm{NO}$, $8 \% \mathrm{O}_{2}, 423 \mathrm{~K}, \mathrm{GHSV}=125,000 \mathrm{~h}^{-1}$ ) over the catalyst reduced and then oxidised.

Acknowledgements

This paper was partially supported by grants from KBN (Grants Nos. 4T09A 12725 and EUREKA "STATIONOCAT" No. 158/E338/ SPB/EUREKA/T-09/DWM126/2004). The High-Resolution Electron Microscopy investigation in Berlin was supported by the SFB 546 of the Deutsche Forschungsgemeinschaft (DFG).

\section{References}

[1] H. Bosch, F. Janssen, Catal. Today 2 (1988) 369.

[2] N.Y. Topsoe, H. Topsoe, J.A. Dumesic, J. Catal. 151 (1995) 226.

[3] U.S. Ozkan, Y. Cai, M. Kumthekar, L. Zhang, J. Catal. 142 (1993) 182.

[4] G.T. Went, L.-J. Leu, R. Rosin, A.T. Bell, J. Catal. 134 (1992) 492.

[5] C. Cristiani, P. Forzatti, J. Catal. 116 (1989) 586.

[6] L. Lietti, P. Forzatti, J. Catal. 147 (1994) 241.

[7] A. Vejux, P. Courtine, J. Solid State Chem. 23 (1978) 93.

[8] L. Casagrande, L. Lietti, I. Nova, P. Forzatti, A. Baiker, Appl. Catal. B: Environ. 22 (1999) 63.

[9] J.C. Védrine (Ed.), EUROCAT oxide Catal. Today 20 (I) (1994) (special issue).

[10] J.C. Védrine (Ed.), EUROCAT II oxide Catal. Today 20 (IV) (1994) (special issue). 
[11] M. Najbar, A. Białas, J. Camra, B. Borzęcka-Prokop, in: Proceedings of the 1st World Congress on Environmental Catalysis, Societa Chimica Italiana Roma, (1995), pp. 283-286.

[12] M. Najbar, J. Banaś , J. Korchowiec, A. Białas, Catal. Today 73 (2002) 249.

[13] J. Banaś, V. Tomasič, A. Wesełucha-Birczyńska, M. Najbar, Catal. Today. (2007).

[14] M. Najbar, F. Mizukami, P. Kornelak, A. Wesełucha-Birczyńska, B. Borzęcka- Prokop, E. Bielańska, A. Białas, J. Banaś , D. Su, Catal. Today 90 (2004) 93.

[15] L.E. Depero, P. Bonzi, M. Musci, C. Casale, J. Solid State Chem. 111 (1994) 247.

[16] L. Depero, J. Solid State Chem. 104 (1993) 470.

[17] In: D.R. Lide (Editor-in-chief), CRC Handbook of Chemistry and Physics, 85th ed., CRC Press, $2004-2005$.

[18] T. Ekström, M. Nygren, Acta Chem. Scand. 26 (1972) 1827.

[19] N. Yamazoe, T. Ekström, L. Kihlborg, Acta Chem. Scand. A29 (1975) 404.

[20] K. Khulbe, R. Mann, A. Manoogien, J. Chem. Phys. 60 (1974) 480.

[21] P. Kornelak, F. Mizukami, A. Wesełucha-Birczyńska, L. Proniewicz, G. Dje'ga Mariadassou, A. Białas, M. Najbar, Catal. Today 90 (2004) 103.

[22] C.D. Wagner, A.V. Naumkin, A. Kraut-Vass, J.W. Allison, C.J. Powell, J.R. Rumble Jr, NIST X-ray Photoelectron Spectroscopy Database, NIST Standard Reference Database 20, Version 3.4 (Web Version), Distributed by the Measurement Services Division of the National Institute of Standards and Technology (NIST) Technology Services, http://srdata.nist.gov/xps/.

[23] R. Benoit, CNRS Orléans, http://www.lasurface.com.

[24] C.D. Wagner, W.M. Riggs, L.E. Davis, J.F. Moulder, G.E. Mullenberg (Eds.), Handbook of X-ray Photoelectron Spectroscopy, PerkinElmer Corporation, Physical Electronics Division, 1978.

[25] A. Katrib, A. Benadda, J.W. Sobczak, G. Maire, Appl. Catal. 242 (2003) 31.

[26] Practical surface analysis, D. Briggs, M.P. Seah (Eds.), second ed., Auger and X-ray Photoelectron Spectroscopy, vol. 1, John Willey \& Sons Ltd., 1990, pp. 636.

[27] H. Klug, L. Alexander, X-ray Diffraction Procedures, Wiley, New York, 1974, p. 687.

[28] P. Kornelak, M. Łabanowska, W. Macyk, E. Bielańska, L. Lityńska-Dobrzyńska, M. Najbar, submitted for publication.

[29] M.A. Larrubia, G. Busca, Mater. Chem. Phys. 72 (2001) 337.

[30] L. Kihlborg, Ark. Kemi 21 (1963) 427.

[31] L. Kihlborg, Acta Chem. Scand. 14 (1960) 1612; L. Kihlborg, Acta Chem. Scand. 17 (1963) 1485.

[32] M. Najbar, J. Camra, A. Białas, A. Wesełucha-Birczyn' ska, B. Borzęcka-Prokop, L. Delevoye, J. Klinowski, Phys. Chem. Chem. Phys. 1 (1999) 4645.

[33] M. Che, A.J. Tench, J. Adv. Catal. 31 (1982) 77.

[34] L. Lietti, G. Ramis, F. Berti, G. Toledo, D. Robba, G. Busca, P. Forzatti, Catal. Today 42 (1998) 101.

[35] X. Yin, A. Fahmi, H. Han, A. Endou, S. Salai Cheettu Ammal, M. Kubo, K. Teraishi, A. Miyamoto, J. Phys. Chem. B 103 (1999) 3218.

[36] J.M. Herrmann, J. Disdier, Catal. Today 56 (2000) 389. 